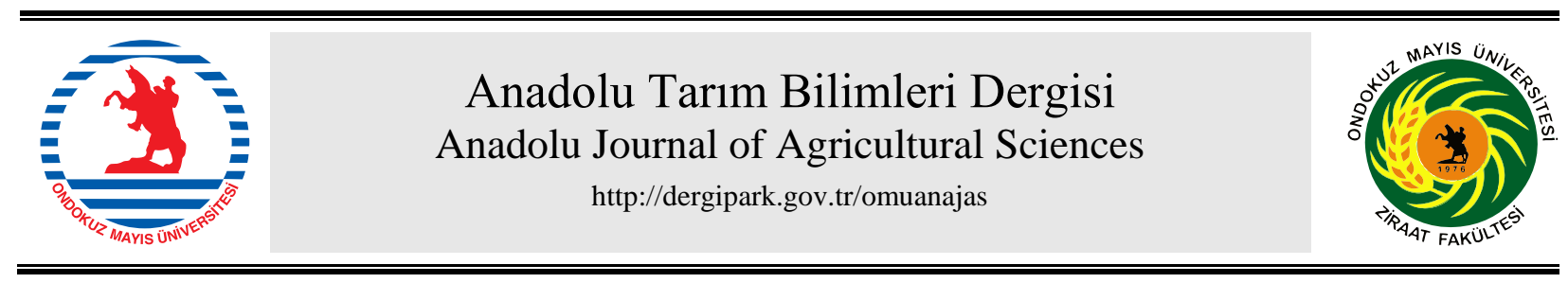

Araştırma/Research

Anadolu Tarım Bilim. Derg./Anadolu J Agr Sci, 36 (2021)

ISSN: 1308-8750 (Print) 1308-8769 (Online)

doi: 10.7161/omuanajas.911128

\title{
Effects of seed sowing methods on emergence and seedling growth of some Rhododendron species
}

\author{
Tuğba Yücel Yazıcı ${ }^{\mathrm{a}}$, ๑ Bahadır ALTUN ${ }^{\mathrm{b} *}$
}

\footnotetext{
${ }^{a}$ Kırşehir Ahi Evran University, Graduate School of Natural and Applied Sciences, 40200 Kırşehir-Turkey

${ }^{\mathrm{b}}$ Kırşehir Ahi Evran University, Faculty of Agriculture, Department of Horticulture, 40200 Kırşehir-Turkey
}

*Sorumlu yazar/corresponding author: bahaltun@gmail.com

Geliş/Received 14/06//2021 Kabul/Accepted 04/08/2021

\begin{abstract}
This study was conducted to determine the effects of different seed sowing methods on emergence rate, densities of seedling emergence and seedling growth of five Rhododendron species $(R$. ponticum L., $R$. luteum Sweet, $R$. caucasicum Pallas, $R$. simirnowii Trautv and $R$. ungernii Trautv). Four different sowing methods were tested, manual sowing in a row (control), mixing with plant agar, mixing with Murashige and Skoog Basal medium (MS) and mixing with stream sand. The highest seed emergence rates were obtained by manual sowing in a row (control) with $R$. ponticum species $(76 \%)$ followed by R. luteum (66.6\%), R. smirnowii (55.33\%), R. ungernii $(24 \%)$ and $R$. caucasicum (15.33\%), respectively. Similarly, the values closest to ideal seed distribution for homogenous seedling density were obtained by hand-sowing in row method. The highest seedling height was obtained in MS medium with $R$. ponticum $(2.11 \mathrm{~cm})$, followed by $R$. luteum $(3.08 \mathrm{~cm}), R$. smirnowii $(4.07 \mathrm{~cm})$, and $R$. ungernii $(1.39 \mathrm{~cm})$, while the effect of the seeding method on seedling growth of $R$. caucasicum species was not significant. To conclude, the best homogeneous distribution of seedling emergence densities of Rhododendron species was obtained by a controlled manual seeding method. However, the seed sowing with MS mixing increased significantly seedling growth in all Rhododendron species.
\end{abstract}

Farkl1 tohum ekim yöntemlerinin orman gülü (Rhododendron ssp.) tohumlarının çıkışları ve fide gelişimi üzerine etkileri

\section{ÖZET}

$\mathrm{Bu}$ araştırma, orman gülü türlerinin (Rhododednron ponticum L., R. luteum Sweet, $R$. caucasicum Pallas, $R$. simirnovii Trautv ve $R$. ungernii Trautv) tohumlarınına uygulanan farklı tohum ekim yöntemlerinin çıkış süresi, fide çıkış sıklıkları ve bitki büyümesine olan etkilerini belirlemek amacıyla yürütülmüştür. Ekim yöntemi olarak, elle sıraya ekme (kontrol), plant agar ile karıştırma, MS ile karıştırma ve dere kumu ile karıştırma olmak üzere dört farklı tohum ekim yöntemi denenmiştir. Araştırmamız sonucunda, en yüksek tohum çıkışı oranları $R$. ponticum türünde $\% 76, R$. luteum \% 66.6, R. smirnovii \% 55.33, R. ungernii \% 24 ve $R$. caucasicum \% 15.33 olarak elle siraya ekme (kontrol) uygulamasından elde edilmiştir. Benzer şekilde, homojen fide sıklığı bakımından da ideal tohum dağılımına en yakın değerler elle sıraya ekme yönteminden elde edilmiştir. Fide boylarında en iyi sonuç $R$. ponticum $(2.11 \mathrm{~cm}), R$. luteum $(3.08 \mathrm{~cm}), R$. smirnovii $(4.07 \mathrm{~cm}), R$. ungernii $(1.39 \mathrm{~cm})$ türlerinde MS ortamından alınmışken, $R$. caucasicum türünde tohum ekim yönteminin fide gelişimi üzerine etkisi olmamıştır. Sonuç olarak orman gülü türlerinin generatif yöntemle çoğaltılmasında fide çıkış sıklıklarının homejen dağılması için elle kontrollü ekim yönteminin en iyi sonucu verdiği halde, MS ile karıştırarak yapılan tohum ekim yönteminin tüm Rhododendron türlerinde fide gelişimini dikkat çekici bir oranda arttırdığı belirlenmiştir.
Keywords:

Rhododendron

Seed

Sowing medium

MS

Agar

Sand
Anahtar Sözcükler: Rhododendron Tohum Ekim ortamı MS Agar Kum 


\section{Introduction}

Rhododendron contains quite different sizes and shapes including low height ground cover to medium-sized shrub or tree. Some cultivars form a rounded habitat, while others may be in the form of an open shrub or an upright growing tree (Cullen, 2005; Shen et al., 2015; Francon et al., 2017; Li et al., 2018). Some species are deciduous, while others are evergreen. Rhododendron species have a wide range of use due to their unique characteristics. These plants can be used as an accent plant, especially in outdoor landscape planning, as border plants alone or along with other shrubs, and tall ones as curtain plants. Natural and cultivated Rhododendron species, and cultivars obtained by various breeding methods decorate the gardens in many countries with their showy flowers (Hay et al., 2006; Weia et al., 2018).

Rhododendron taxa, a precious ornamental plant, can be reproduced by generative or vegetative methods similar to many other cultivated plants. Rhododendron taxa in nature, which have high germination ability and produce many seeds depending on the species, are produced with their seeds and underground stems. The seedlings can be propagated using modern techniques such as cutting, grafting, layering methods and tissue culture (Altun, 2011; Elmongy et al., 2018).

Cross-pollination occurs in Rhododendron due to its hermaphrodite flower structure. Pollination is generally done by bees. However, recent reports indicated that some insects, birds and squirrel breeds are also effective in pollination (Georgian et al., 2015). Therefore, intermediate species and their hybrid individuals and pure species can be encountered in the natural flora (Milne et al., 1999; Altun and Çelik, 2016; Zhang et al., 2017). Reproduction with seed, easy and natural method, is a suitable method to obtain new hybrid plants in breeding studies or obtain rootstocks in grafting studies.

The fruit of Rhododendron is a septicite capsule (Y1ldiz and Aktoklu, 2010). The quite small seeds in the fruits can be broad-winged, narrow-winged or without wings. The average 1000-seed weight of Rhododendron species in Turkey was reported between $0.142 \mathrm{~g}$ and $0.067 \mathrm{~g}$ (Altun, 2011). The seeds do not need any chilling requirements due to the higher germination and emergence rates, depending upon species (Ryabova and Zueva, 1993; Sakharova, 1993; Arocha et al., 1999; Glenn et al., 1999; Basnet, 2005; Vologdina, 2006; Altun, 2011). Seeds need light to germinate (Vologdina, 2006); therefore, seeds must be sown superficially during planting and not be covered.

The main problems in generative reproduction of small seed plants are irregular emergence, seed losses during planting and seedling losses in transplanting. Rhododendron, which has very small seeds, cannot be planted homogenously in seed reproduction and a homogeneous emergence cannot be obtained in seedling emergence. Seedling losses occur in very dense seedlings during transplanting. The classical manual spreading method is used to sow Rhododendron seeds despite mixing the seeds with various materials such as sand or sawdust to minimize the losses in many plant species with small seeds and obtain a homogeneous emergence. The effects of many factors such as photoperiod (Li et al., 2012; Chen and Sheng, 2017), different mediums, temperatures, seeding depths (Vologdina, 2006; Jin et al., 2007), seed sowing times (Tewari and Tewari, 2019), various stress factors (Chang et al., 2015; Pan et al., 2018), pre-treatments (Vipasha and Kaler, 2018), and seed preservation temperatures and durations (Juan et al., 2014) were investigated on the germination and emergence of Rhododendron seeds. However, the studies conducted to determine the effects of different seed sowing methods on the emergence rates and seedling emergence homogeneity of Rhododendron seeds are lacking in the literature. In the current study, different alternative seed sowing methods were tested in Rhododendron reproduction. This study was conducted to investigate the effects of different sowing methods on seed emergence rate, homogeneity of the interrow and intra row seedling distances and seedling growth of five natural Rhododendron species collected from the Black Sea Region of Turkey.

\section{Materials and Methods}

\subsection{Plant material}

The seeds of five Rhododendron species ( $R$. luteum Sweet, $R$. ponticum L., $R$. ungernii Trautv, $R$. simirnowii Trautv, $R$. caucasicum Pallas), collected from natural distribution areas in Artvin province and district boundaries, were used as plant material of the experiment (Table 1). 
Table 1. Information of the locations where Rhododendron seeds collected Çizelge 1. Rhododendron tohumlarınin alındiklart yerlere ait veriler

\begin{tabular}{|c|c|c|c|}
\hline Species & Altitude & Coordinate & Location \\
\hline R. ponticum $\mathrm{L}$. & $1652 \mathrm{~m}$ & $41^{\circ} 08^{\mathrm{ee}} 914 \mathrm{~K} / 41^{\circ} 46^{\mathrm{ec}} 205 \mathrm{D}$ & Artvin \\
\hline R. luteum Sweet & $1671 \mathrm{~m}$ & $41^{\circ} 10^{\circ e} 424 \mathrm{~K} / 42^{\circ} 18^{\circ e} 943 \mathrm{D}$ & Şavşat \\
\hline R. simirnowii Trautv. & 1982 m & $40^{\circ} 14^{\mathrm{ec}} 743 \mathrm{~K} / 41^{\circ} 35^{\mathrm{ce}} 699 \mathrm{D}$ & Murgul \\
\hline R. ungernii Trautv. & $1249 \mathrm{~m}$ & $41^{\circ} 18^{\mathrm{ee}} 870 \mathrm{~K} / 41^{\circ} 53^{\mathrm{ec}} 495 \mathrm{D}$ & Borçka \\
\hline R. caucasicum Pallas & $2289 \mathrm{~m}$ & $41^{\circ} 43^{\circ} 450 \mathrm{~K} / 42^{\circ} 28^{\mathrm{e}} 376 \mathrm{D}$ & Şavşat \\
\hline
\end{tabular}

\subsection{Collection of seeds and preparation for the sowing}

The seeds were pooled when the capsules ripened and turned brown, before opening and dispersing the seeds, stored into dry pouch paper (Altun, 2011), and transported to the laboratory. The seed capsules were placed in the containers in air-dry room conditions at the laboratory and waited until the capsules were totally opened. The seeds were passed through a $0.850 \mathrm{~mm}$ mesh sieve to clean the materials, such as plant parts in the seeds that came from the opened capsules. The cleaned seeds were placed in dry glass jars for storage and kept at $22 \pm 2{ }^{\circ} \mathrm{C}$ under laboratory conditions until the emergence tests commenced.

\subsection{Experimental design}

Sterile acidic peat $(\mathrm{pH}=3.5-4.5)$ was used as a germination medium. Four different seed sowing methods were applied, namely control, Plant agar medium (Duchefa Biochemie), Murashige and Skoog Basal medium (MS) (Sigma) and mixing with stream sand. The classical manual sowing method was applied in the control treatment. The experiments were conducted in four climate chambers $(75 \times 65 \times 60 \mathrm{~cm})$ in the laboratory of the Horticulture Department of Agriculture Faculty in Kirsehir Ahi Evran University. The experimental design was randomized plots with three replications, and each consists of 50 seeds.

\subsection{Seed sowing}

The seeds were sown in foam containers $(35 \times 50 \mathrm{~cm})$ placed in climate chambers. The foam containers were filled with sterile acidic peat for each treatment and a smooth surface was obtained by leveling the container surface. Peat was moistened by a hand sprayer and seeds were sown superficially by the methods mentioned above.

The seeds were sown as $4 \mathrm{~cm}$ between species and $2 \mathrm{~cm}$ between replicates. The containers were slightly irrigated with a hand sprayer after sowing the seeds, and the containers were placed inside the climate chamber. The temperature and humidity values were recorded hourly from November 3, 2016 till December 28, 2016 and seed emergences were counted. The average temperature during emerging was $18.12{ }^{\circ} \mathrm{C}$, and the average humidity was $64.58 \%$.

The seeds in the control group were placed on small papers and evenly distributed on the peat surface by slightly tapping them In the sowing method with stream sand, 50 seeds were mixed with $5 \mathrm{cc}$ of stream sand. This mixture was equally transferred to the peat surface over the V-shaped cardboard. In the MS medium (Murashige and Skoog, 1962) and Plant Agar (Sağlam, 2009) mixing method, $30 \mathrm{ml}$ substrate was transferred into paper cups. The seeds were added into the paper cups and mixed until obtaining a homogeneous mixture. The nutrient medium + seed mixture was placed on aluminum foil as $30 \mathrm{~cm}$ thin strips then, transferred over the peat using aluminum foil.

\subsection{Seed emergence trials}

The seed emergence was controlled regularly every seven days from seed sowing (Hay et al., 2006). Emerging seeds were counted with a magnifying glass and the data were routinely recorded on the seed emergence sheet. Counting was continued until the number of emerged seeds became constant. The seed emergence rates were calculated in percent.

\subsection{Determination of the planting methods effect on seedling density}

The distance among seedlings was measured by a caliper and values were obtained after the seed emergence rate became constant. These values were noted on a graph paper and recorded. The seedling locations marked on graph paper were transferred to the computer and schematized using the AutoCAD software. The seedling emergence density was determined visually by comparing the ideal seedling emergence distribution with the seedling emergence schematized by the AutoCAD software.

\subsection{Measuring of seedling height}


Six months after the seed sowing seedlings were removed, the height $(\mathrm{cm})$ of each seedling was measured using a ruler and average values were calculated.

\subsection{Statistical analysis}

SPSS 16.0 software was used for statistical analysis. Since the emergence rate values were calculated as percent, the data were normalized using the "ArcSin" transformation. The data obtained were subjected to one-way analysis of variance. The mean values for the treatments were compared by Duncan Multiple Comparison Test. The comparisons and letterings were carried out separately for the species. However, all results were compiled and presented in a single table.

\section{Results and Discussion}

\subsection{Seed emergence rates}

The first emergence was observed nine days after sowing in $R$. luteum and $R$. caucasicum species in the MS environment. The first emergence in the control group was observed 13 days after sowing in $R$. ponticum and $R$. cacucasicum species. Similar to the control group, the first emergence in the plant agar group was observed 13 days after sowing in $R$. luteum, $R$. caucasicum and $R$. ponticum, while the first emergence in river sand was observed 18 days after sowing in $R$. luteum and $R$. ponticum species.

The effect of sowing methods on seed emergence of $R$. ponticum and $R$. caucasicum species was not statistically significant ( $\mathrm{p}>0.05)$, and the seed emergence rates were recorded as 42.66-76.00 and 8.66-15.33\%, respectively (Table 2). In contrast, the effects of sowing methods on seed emergence rates of $R$. luteum, $R$. smirnowii and $R$. ungernii species were statistically significant. The highest emergence rate $(66.6 \%)$ of $R$. luteum variety was obtained in the control method (Table 2). Agar (51.33\%) and MS (50.00\%) mediums were included in the same statistical group, while the lowest seed emergence rate $(24.66 \%)$ was obtained from the seeds sown by mixing with the stream sand. The highest emergence rate $(55.33 \%)$ of $R$. smirnowii seeds was obtained in the control method, followed by the MS medium with an emergence rate of $50.00 \%$. The stream sand $(15.33 \%)$ and agar $(14.00 \%)$ methods, which had lower emergence rates than those of control and MS methods, were statistically placed in the same group. The highest emergence rate $(24.00 \%)$ of $R$. ungernii seeds was obtained in the control method, and the emergence rates of other methods were relatively low compared to the control method.

Table 2. Effects of treatments on seed emergence rate

Çizelge 2. Uygulamaların tohum çıkış oranına etkisi

\begin{tabular}{|c|c|c|c|c|c|c|}
\hline \multirow[b]{2}{*}{ Species } & \multicolumn{4}{|c|}{ Treatments } & \multirow[b]{2}{*}{ SEM } & \multirow[b]{2}{*}{$P$ values } \\
\hline & $\begin{array}{l}\text { Control } \\
(\%)\end{array}$ & $\begin{array}{l}\text { Sand } \\
(\%)\end{array}$ & $\begin{array}{l}\text { Agar } \\
(\%)\end{array}$ & $\begin{array}{l}\text { MS } \\
(\%)\end{array}$ & & \\
\hline R. ponticum & 76.00 & 51.33 & 45.33 & 42.66 & 5.311 & 0.091 \\
\hline R. luteum & $66.66 \mathrm{a}^{\text {** }}$ & $24.66 \mathrm{c}$ & $51.33 \mathrm{~b}$ & $50.00 \mathrm{~b}$ & 4.938 & 0.001 \\
\hline R. smirnowii & $55.33 \mathrm{a}^{* *}$ & $15.33 \mathrm{~b}$ & $14.00 \mathrm{~b}$ & $50.00 \mathrm{a}$ & 6.451 & 0.004 \\
\hline R.ungernii & $24.00 \mathrm{a}$ & $12.66 \mathrm{~b}$ & $10.66 \mathrm{~b}$ & $10.66 \mathrm{~b}$ & 2.061 & 0.029 \\
\hline R.caucasicum & 15.33 & 8.66 & 13.33 & 14.66 & 1.424 & 0.382 \\
\hline
\end{tabular}

* The difference between the averages in the same line and starting with the same letter is statistically insignificant according to Duncan Multiple Comparison Test $(\mathrm{P}<0.05)$.

The seed emergence rates may vary depending on many factors such as plant type, location of plant growth, time of seed collection and storage conditions. The highest seed emergence rate in all Rhododendron species examined in this study was obtained by manual sowing (control) treatment. Vologdina (2006) reported that seeds of Rhododendron dauricum L., $R$. mucronulatum Turcz. and $R$. sichotense Pojark species collected from natural populations are light-sensitive and the emergence rate of all species varied between 73 and $90 \%$. The highest emergence rate in the control method can be explained by the higher light intensity in the seed bed under the control condition during the germination stage. The lowest seed emergence rate in $R$. ponticum species was obtained in the MS treatment, while in $R$. luteum and $R$. caucasicum species by mixing with stream sand treatment. The emergence rates of $R$. fortunei species in leaf rot + sawdust dust and leaf rot + algae mediums were 38.6 and $38.2 \%$ respectively (Jin et al., 2007). The germination of $R$. luteum was reported as $71.0 \%$ (Sakharova, 1993). The seed emergence rate using manual sowing in row method in winter months and under unheated greenhouse conditions was determined as $78.50 \%$ in $R$. poticum, $76.00 \%$ in $R$. luteum, $64.75 \%$ in $R$. smirnowii, $57.25 \%$ in $R$. ungernii 
and $55.50 \%$ in $R$. caucasicum species (Altun and Çelik, 2016). The findings on seed emergence were in line with the findings of other researchers, while lower emergence rates were obtained in $R$. ungernii and $R$. caucasicum species compared to the literature. The seed emergence rates may vary between species. Compared to previous reports, the lower emergence rates of both Rhododendron species may be related to the genetic characteristics of Rhododendron species and their seed qualities. The climate in the seed sampling period was rather extreme than usual, and the seed of many Rhododendron species was not sufficiently ripened before the winter (personal observation). Therefore, the two Rododendron species' seeds in this study may have been harvested before reaching the the generative maturity.

\subsection{Effect of seed sowing methods on seedling density}

There were differences between the number of seed emergences in the replications of Rhododendron species used. Some of the seeds sown in the replicates did not emerge. Therefore, the emergence rate could not be statistically compared with the ideal emergence density. However, the data were transferred to the digital environment to enable a visual comparison and presented with the ideal seed distribution (ISD). The ideal seed distribution expected was shown schematically next to each treatment container and the emerging seed comparisons were made accordingly.

The seedling emergence locations in the control method transferred to the Autocad software were visually compared to determine the closest seed distribution to the ideal seed distribution (Figure 1). The closest result to the ideal seed distribution in the control group occurred in $R$. ponticum and $R$. luteum. The $R$. simirnowii was the third variety, while the least similar seed distribution was obtained in $R$. caucasicum and $R$. ungernii species. The best seed emergence distribution pattern in mixing with river sand method was obtained in $R$. ponticum species, followed by $R$. luteum, R.ungernii, $R$. simirnowii and $R$. caucasicum species, respectively (Figure 2).

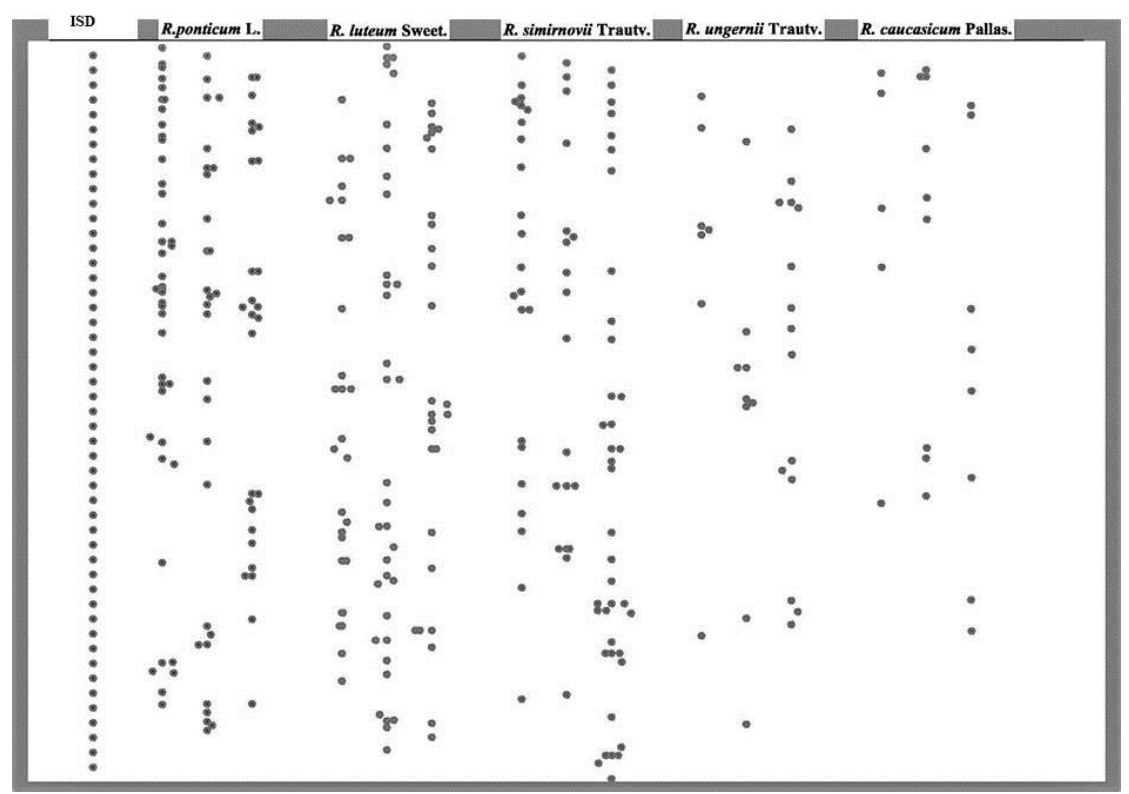

Figure 1. Seed emergence distributions in control method (sowing with manual spreading to the lines). Şekil 1. Kontrol (Elle Sıraya Serpme Ekim) uygulaması tohum çıkış dağıllımları. 


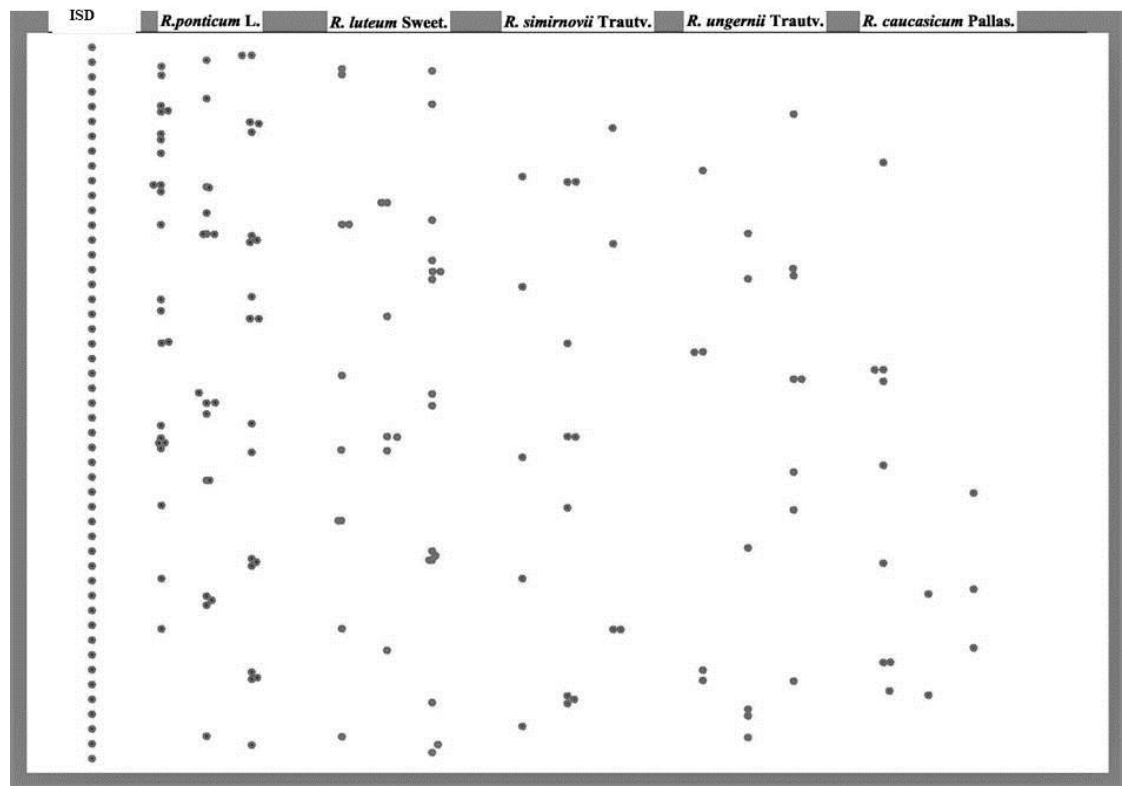

Figure 2. Distributions of seed emergence in the mixing with stream sand (banksand) method.

Şekil 2. Dere kumu ile karıştırılarak ekim uygulaması tohum çıkış dağılımları.

The closest seed emergence distribution in the MS group to the ideal distribution was determined in $R$. luteum species, and followed by $R$. ponticum and $R$. simirnowii species. The seed emergence distribution of $R$. caucasicum was quite far from the ideal distribution.

The seed emergence distribution of $R$. ungernii was determined as the least similar distribution to the ideal distribution (Figure 3). The best seed emergence distribution in the agar medium was found in the $R$. luteum variety, followed by the $R$. ponticum. The species far from the ideal distribution were determined as $R$. caucasicum, $R$. ungernii and $R$. simirnowii (Figure 4).

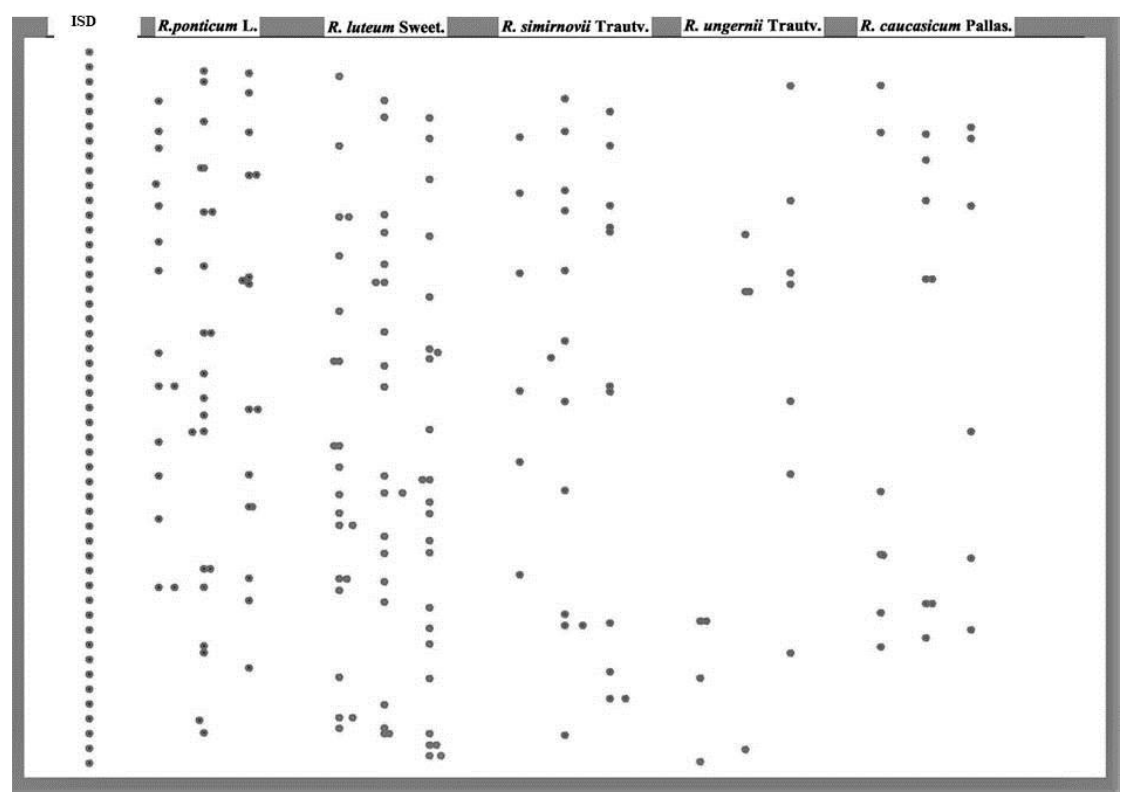

Figure 3. Distribution of seed emergence in the MS method.

Şekil 3. MS uygulaması tohum çıkış dağılımları. 


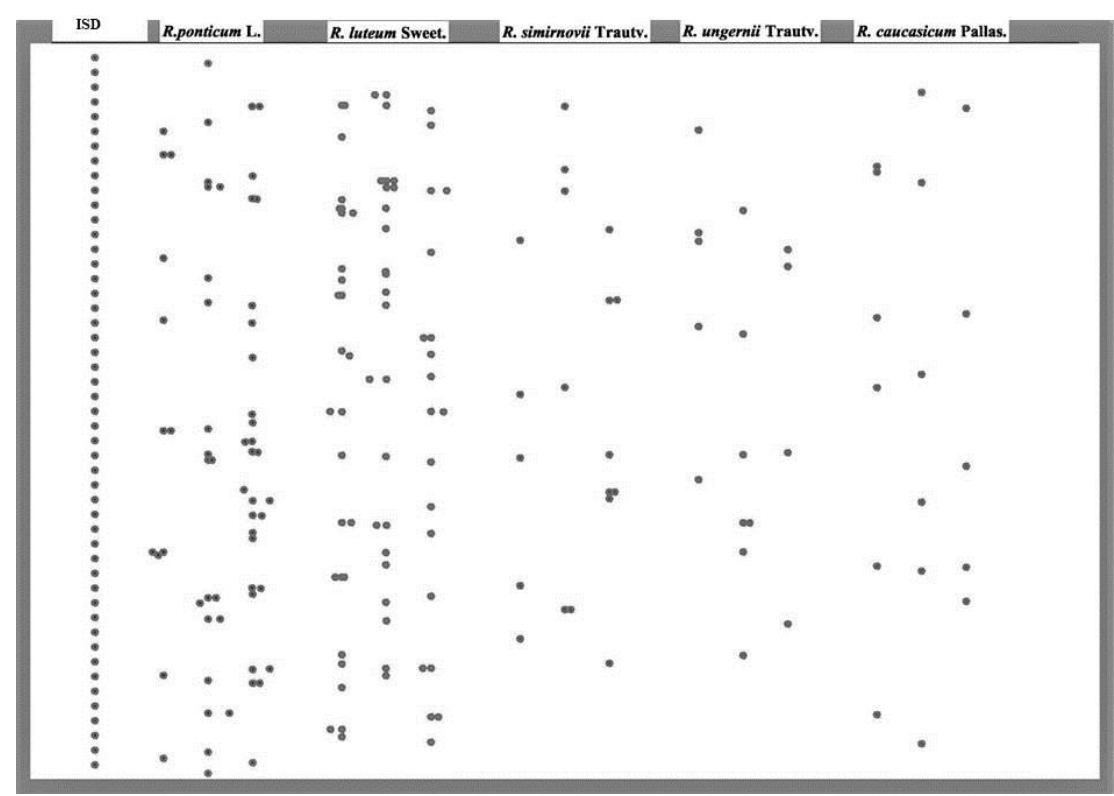

Figure 4. Distribution of seed emergence in the agar treatment.

Şekil 4. Agar ile karıştırılarak ekim uygulaması tohum çıkışlarının dă̆ıllımları.

In this study, a new technique, which is not available in the literature, was introduced to compare the seedling density. In this technique, the measured seedling distances were transferred into the AutoCAD software. The seedling density of the ideal distribution for each variety was compared with the AutoCAD images. The examination of the image indicated that the most density in seedling emergence occurred in the control method. The finding may be related directly to the amount of light received by the seeds. For example, some seeds mixing with river sand treatment probably could not receive sufficient light due to the cover of sand grains and therefore could not germinate. The seed emergences in plant agar and MS mediums were higher than the stream sand, but the seedlings were sparsely located and even there were some clusters of seedlings. Plant Agar and MS mediums were prepared hot; therefore, both have to be cooled for seed sowing. Cooling mediums, on the other hand, turn into a solid gel consistency, which may be broken down by mixing. The seeds were added into both media by thoroughly mixing before entirely solidify to obtain a homogeneous seed distribution. The viability of seeds may have been impaired in hot mediums used, and thus the seed emergence may have been influenced and caused sparse seed emergences. Clustering may indicate an incomplete mixture, or the mixture may have carelessly transferred into the germination medium and not homogenously mixed. Since seedlings covered a large part of the germination area, the seedling distribution pattern in the control application which had the highest number of seed emergence was credited as the closest sowing method to the ideal seed distribution.

\subsection{Effects of sowing methods on seedling height}

The effects of seed sowing methods on seedling heights of $R$. ponticum, $R$. luteum and $R$. smirnowii species were statistically very significant $(\mathrm{p}<0.01)$ (Table 3 ). In contrast, the effect of treatments on R.ungernii and $R$. caucasicum species' seedlings was not statistically significant $(\mathrm{p}>0.05)$.

Table 3. Effect of treatments on seedling heights

Çizelge 3. Uygulamaların fide boylarına etkisi

\begin{tabular}{|c|c|c|c|c|c|c|}
\hline \multirow{2}{*}{ Species } & \multicolumn{4}{|c|}{ Methods } & \multirow{2}{*}{ SEM } & \multirow{2}{*}{$P$ values } \\
\hline & Control & Sand & Agar & MS & & \\
\hline R. ponticum & $1.02 b^{*}$ & $1.17 \mathrm{~b}$ & $0.89 \mathrm{c}$ & $2.11 \mathrm{a}$ & 0.147 & 0.00 \\
\hline R. luteum & $1.44 b^{*}$ & $1.48 \mathrm{~b}$ & $1.49 \mathrm{~b}$ & $3.08 \mathrm{a}$ & 0.213 & 0.00 \\
\hline R. smirnowii & $1.07 b^{*}$ & $0.98 \mathrm{~b}$ & $0.95 \mathrm{~b}$ & $4.07 \mathrm{a}$ & 0.409 & 0.00 \\
\hline R.ungernii & 1.00 & 0.62 & 0.93 & 1.39 & 0.120 & 0.14 \\
\hline R.caucasicum & 1.08 & 0.80 & 1.69 & 1.43 & 0.141 & 0.10 \\
\hline
\end{tabular}

*The difference between the averages in the same line and starting with the same letter is statistically insignificant according to Duncan Multiple Comparison Test $(\mathrm{P}<0.05)$. 
The best seedling growth (mean seedling height of $2.11 \mathrm{~cm}$ ) in $R$. ponticum species was obtained in seeds sown by mixing with MS medium. The mean height of seedlings obtained from seeds sown in control and stream sand treatments, included in the same statistical group, was measured as 1.02 and $1.17 \mathrm{~cm}$, respectively. The lowest effect on the seedling length was recorded in the plant agar medium and the mean seedling height was $0.89 \mathrm{~cm}$.

Similarly, the better seedling heights in $R$. luteum (Figure 5) and $R$. smirnowii species were obtained in MS medium with $3.08 \mathrm{~cm}$ and $4.07 \mathrm{~cm}$, respectively. Control $(1.44 \mathrm{~cm})$, stream sand $(1.48 \mathrm{~cm})$, and plant agar $(1.49 \mathrm{~cm})$ methods were statistically in the same group. Similarly, all methods in the $R$. smirnowii species, except for the MS medium, were statistically in the same group. The plant heights obtained from $R$. smirnowii were 1.07, 0.98 and 0.95 $\mathrm{cm}$ for control, stream sand and plant agar methods, respectively.

Different seed sowing methods did not have a significant effect ( $\mathrm{p}>0.05)$ on seedling growth of $R$. ungernii and $R$. caucasicum species (Table 3). The seedling height of $R$. ungernii ranged from 0.62 to $1.39 \mathrm{~cm}$, while the seedling height of $R$. caucasicum was between $0.80 \mathrm{~cm}$ and $1.69 \mathrm{~cm}$. However, the highest seedling $(1.39 \mathrm{~cm})$ in $R$. ungernii was obtained in the MS medium.

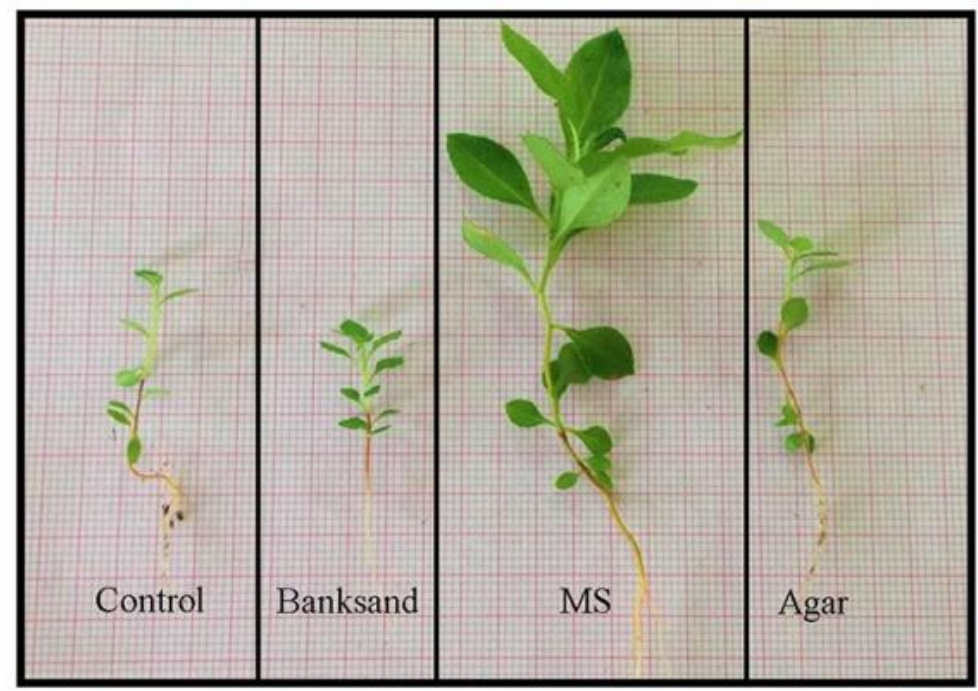

Figure 5. Effects of sowing mediums on plant heights of R. luteum.

Şekil 5. Ekim ortamlarının R. luteum'un fide boylarına etkisi.

The results revealed that different seed sowing methods did not affect the seedling growth of $R$. ungernii and $R$. caucasicum. Conversely, the best outcomes in $R$. ponticum, $R$. luteum and $R$. simirnowii species were obtained by applying MS medium. Investigating the effects of various physical and chemical factors and plant growth regulators to increase the uniform seed germination, Tiwari and Chauhan (2007) found that only a few among plant growth regulators and chemicals on seed germination were significant compared to the control. The maximum seed germination was reported in $R$. maddenii and $R$. niveum using $250 \mu \mathrm{M}$ GA3 added MS medium. Parmar et al. (2015) investigated in vitro seed germination and seedling growth of Coelogyne flaccida Lindl., an orchid species. They reported that the MS medium enriched with $0.5 \mathrm{mg} \mathrm{L}^{-1} \mathrm{BAP}$ and $0.5 \mathrm{mg} \mathrm{L}^{-1} \mathrm{NAA}$ was optimal for the growth of the whole seedlings. The highest germination percentage $(60.25 \%)$ was obtained in garden soil + sand + barn manure (1:1:1) medium at a study conducted to reproduce Sand Lily (Pancratium maritimum L.) using seeds under in vitro and in vivo conditions (Kanmaz, 2013).

The findings on the very significant effect of mediums on the growth of Rhododendron seedlings are similar to those of mentioned above studies. Nutrient-enriched growing medias are ideal for the emergence and rapid growth of Rhododendron seedlings. Considering the prolonged growth of rhododendrons, the results of this study indicating the increase of two times larger seedlings than control, are very important in terms of cultivation.

\section{Result}

The data obtained in this study show that manual sowing was the best method to obtain a more homogeneous distribution between the interrow and intra row distances in the generative reproduction of Rhododendron species. However, sowing by mixing with the MS medium gave much better results for seedling growth than the classical method. It increased the seedling growth of all Rhododendron species investigated almost two folds compared to other applications. Accelerating the seedling growth is a significant benefit considering the Rhododendron species are very slow-growing plants. The present findings gave ideas to solve the problems experienced in the generative 
reproduction of Rhododendron species. Future studies to be conducted to determine the factors affecting the decrease in seed emergence in sowing to the MS media, the causes for the disruption of homogeneity in the distribution of seedlings, and the solutions to eliminate the stated deficiencies will make an essential contribution to the literature.

\section{Acknowledgement}

The seed materials of this study were obtained from a natural spreading location, under the concept of TUBITAK Project with registered number 112O500. That is why the authors thank TUBITAK for funding.

\section{References}

Altun, B., 2011. Collection and Cultivation of Turkey Rhododendrons. PhD Thesis. Ondokuzmayis University Institute of Science, p.244. Samsun.

Altun, B., Çelik, H., 2016. Determination Of Propagation Performance From Seeds In Rhododendron Species. VII International Scientific Agriculture Symposium, 889-894, October 06 - 09, Jahorina.

Arocha, L.O., Blazich, F.A., Warren, S.L., Thetford, M., Berry, J.B., 1999. Seed germination of Rhododendron chapmanii: influence of light and temperature. Journal of Environmental Horticulture, 17(4):193-196.

Basnet, D.B., 2005. Seed collection and cultivation of Rhododendron arboreum Smith. Indian Journal of Forestry, 28(3):239-242.

Chang, L., Le, S.J., Qing, L.X., Si, H.L., Ping, C.S., Zheng, X., Fa, X.C., 2015. Effects of drought stress on seed germination and seedling physiological characteristics of Rhododendron latoucheae. Acta Botanica BorealiOccidentalia Sinica, 35(7):1421-1427.

Chen, L.L., Sheng, W.C., 2017. Influence of light intensity and photoperiod on the seed germination of four Rhododendron species in Taiwan. Pakistan Journal of Biological Sciences, 20(5): 253-259.

Cullen, J., 2005. Hardy Rhododendron Species A Guide to Identification. Timber Press, Inc, p. 496.

Elmongy, M.S., Zhoua, H., Caoa, Y., Liua, B., Xiaa, Y., 2018. The effect of humic acid on endogenous hormone levels and antioxidant enzyme activity during in vitro rooting of evergreen azalea. Scientia Horticulturae, 227, 234-243.

Francon, L., Corona, C., Roussel, E., Saez, J.L., Stoffel, M., 2017. Warm summers and moderate winter precipitation boost Rhododendron ferrugineum L. growth in the Taillefer massif (French Alps). Science of the Total Environment, 586, 1020-1031.

Georgian, E., Fang, Z., Emshwiller1, E., Pidgeon, A., 2015. The Pollination Ecology of Rhododendron floccigerum Franchet (Ericaceae) In Weixi, Yunnan Province, China. Journal of Pollination Ecology, 16(11):72-81.

Glenn, C.T., Blazich, F.A., Warren, S.L., 1999. Secondary seed dormancy of Rhododendron catawbiense and Rhododendron maximum. Journal of Environmental Horticulture, 17(1):1-4.

Hay, F., Klin, J., Probert, R., 2006. Can a post-harvest ripening treatment extend the longevity of Rhododendron L. seeds?. Scientia Horticulturae, 111: 80-83.

Jin, P.F., Bian, C.M., Yang, W., Ke, J.M., 2007. Seed breeding and sapling transplantation of Rhododendron fortunei in Linhai. Journal of Zhejiang Forestry Science and Technology, 27(2):34-36.

Juan, Z.X., Ming, Z.Y., Man, L.J., Ming, Z.Y., Zhong, H.C., 2014. Effects of storage temperature and time on seed germination of Rhododendron delavayi. Journal of Southwest Forestry University, 34(5):59-63.

Kanmaz, E., 2013. A study on propagation of sand lily (Pancratium maritimum L.) by seed in vivo and in vitro conditions. Master Thesis. Adnan Menderes University Institute of Science, p. 79. Aydın.

Li, Z.J., Wen, W.Y., Zhi, W.H., Zhou, Z.H., Yue, W.Y., 2012. Studies on seed germination of four species of Subgen. Hymenanthes (Blume) K. Koch (Ericaceae) in Yunnan. Journal of Yunnan Agricultural University, 27(6) 875-881.

Li, S., Sun, W., Ma., 2018. Does the giant tree Rhododendron need conservation priority?. Global Ecology and Conservation, 15, e00421.

Murashige, T., Skoog, F., 1962. A revised medium for rapid growth and bioassays with tobacco tissue cultures. Physiol. Plant, 15:473-497.

Milne, R. I., Abbott, J.R., Wolff, K., Chamberlain, D.F., 1999. Hybridization among Sympatric Species of Rhododendron (Ericaceae) In Turkey: Morphological and Molecular Evidence. American Journal of Botany, 86(12): 1776-1785.

Pan, L., Min, G.X., Na, L., 2018. Effects of irradiation on Rhododendron seed germination and seedling growth under saline and alkaline stress. Journal of Southern Agriculture, 49(3): 516-524.

Parmar, G., Pant, B., 2015. In vitro seed germination and seedling development of Coelogyne flaccida Lindl. (Orchidaceae). Advances in Forestry Science, 2(4): 85-88. 
Ryabova, N.V., Zueva, E.N., 1993. Propagation and growing of ornamental shrubs with small seeds. Byulleten' Glavnogo Botanicheskogo Sada, 167:8-13.

Sağlam S., 2009. Research on Obtaining Transgenic Bean (Phaseolus vulgaris L.) Plants Resistant to Seed Insects (Bruchidae: Coleoptera). PhD Thesis. Ankara University, p.108. Ankara.

Sakharova, S.G., 1993. Laboratory germination of Rhododendron seeds. Byulleten' Glavnogo Botanicheskogo Sada, 167:124-129.

Shen, S.K., Wu, F.Q., Yang, G.S., Wang, Y.H., Sun, W.B., 2015. Seed germination and seedling emergence in the extremely endangered species Rhododendron protistum var.giganteum - the world's largest Rhododendron. Flora, 216:65-70.

Tewari, B., Tewari, A., 2019. Capsule maturation timing in Rhododendron arboreum Smith in the Central Himalayan Region. Indian Journal of Ecology, 46(4):768-771.

Tiwari, O.N., Chauhan, U.K., 2007. Seed germination studies in Rhododendron maddenii Hook. f. and Rhododendron niveum Hook. f. Indian Journal of Plant Physiology, 12(1):50-56.

Vipasha Sanyam, Kaler, N.S., 2018. Pre-sowing seed treatment effect on germination behaviour of Rhododendron. Journal of Hill Agriculture, 9(2):244-246.

Vologdina, O.S., 2006. Biology of Rhododendron dauricum, R. mucronulatum and R. sichotense (Ericaceae) seeds germination. Rastitel'nye Resursy, 42(2):55-60.

Weia, X., Chenb, J., Zhangc, C., Wanga, Z., 2018. In vitro shoot culture of Rhododendron fortunei: An important plant for bioactive phytochemicals. Industrial Crops \& Products, 126, 459-465.

Yıldı, B., Aktoklu, E., 2010. Plant Systematics from the First Terrestrial Plant one dicotyledons. Palme Publishing, Ankara.

Zhang, J.L., Ma, Y.P., Wu, Z.K., Dong, K., Zheng, S.L., Wang, Y.Y., 2017. Natural hybridization and introgression among sympatrically distributed Rhododendron species in Guizhou, China. Biochemical Systematics and Ecology, 70, 268-273. 